\title{
PHENOLOGICAL DEVELOPMENT AND PRODUCTION POTENTIALS OF TOMATO UNDER POLYHOUSE CLIMATE
}

\author{
M.R. Parvej ${ }^{1}$, M.A.H. Khan ${ }^{2}$ and M.A. Awal ${ }^{2}$
}

\begin{abstract}
An experiment was conducted in a covered polyhouse along with an open field (control) aside the Field Laboratory of the Department of Crop Botany, Bangladesh Agricultural University, Mymensingh during the period from December 2007 to April 2008 to compare the phenological development and production potentials of two tomato varieties viz. BARI Tomato-3 and Ratan under polyhouse and open field conditions. Photosynthetically active radiation inside the polyhouse was reduced by about $40 \%$ compared to the outside (i.e. open field) while air and soil temperatures were always remained higher. From December to February the mid day air temperature under polyhouse and open field varied from 31.8 to $39.1^{\circ} \mathrm{C}$ and 23.3 to $31.1^{\circ} \mathrm{C}$, respectively indicating about $8^{\circ} \mathrm{C}$ higher air temperature inside polyhouse and during that time the average air temperature inside polyhouse was about $28^{\circ} \mathrm{C}$ which was optimum for the growth and development of tomato plants. Relative humidity had opposite trends with that of air temperature i.e. it was lower inside the polyhouse as compared to open field. The above microclimatic variabilities inside polyhouse favoured the growth and development of tomato plant through increased plant height, number of branches/plant, rate of leaf area expansion and leaf area index over the plants grown in open field. Flowering, fruit setting and fruit maturity in polyhouse plants were advanced by about 3,4 and 5 days, respectively compared to the crop raised in open field condition. Polyhoused plants had higher number of flower clusters/plant, flowers/cluster, flowers/plant, fruit clusters/plant, fruits/cluster and fruits/plant, and fruit length, fruit diameter, individual fruit weight, fruit weight/plant and fruit yield over open field condition. The fruit yield obtained from the polyhouse was 81 t/ha against 57 t/ha from the open field.
\end{abstract}

Key worlds: Phenological development, polyhouse climate, production potentials, tomato.

\section{INTRODUCTION}

Tomato (Licopersicon esculentum Mill.) belongs to the Solanaceae is one of the most popular and nutritious vegetable crops all over the world including Bangladesh. The total production of tomato in Bangladesh was about 137000 tons from 17900 hectares of land with an average yield of $7.65 \mathrm{t} \mathrm{ha}^{-1}$ (BBS, 2008) which is very low as compared to the other tomato producing countries. Moreover, the production of tomato in our country lags behind the demand. Conventional cultural practices and mere application of chemical fertilizers are not enough to fill-up the gaps between production and demand. Therefore, a sustainable and low cost technology for tomato cultivation is urgent in Bangladesh.

Phenological development governs the plant growth and productivity (Awal and Ikeda, 2003b). Days to flowering, fruiting and maturity of crop are the important phenological events which determine the productivity of a crop. Temperature plays a major role in phenological development and productivity of crop plants. High temperature influences crops to mature

\footnotetext{
${ }^{1}$ Department of Seed Science and Technology,Bangladesh Agricultural University,Mymensingh-2202, Bangladesh.

${ }^{2}$ Laboratory of Plant Ecology,Department of Crop Botany,Bangladesh Agricultural University,Mymensingh-2202, Bangladesh.
} 
earlier (Awal et al., 2003). Tomato plant grown under polyhouse was observed to be earlier in flowering and fruit setting by about 3 and 8 days, respectively when compared to the crop raised under open condition (Ganesan, 2002b). The early and higher yield of different vegetable crops inside the polyhouse was mainly because of better microclimate such as higher temperature $\left(4-9^{\circ} \mathrm{C}\right.$ than the nearby open field) observed during winter months (Cheema et al., 2004). Therefore, the polyhouse environment may provide a new scope for commercial production of high value vegetable crops like tomato. It has been in use for vegetable production with far better yield in more than fifty countries all over the world (Kanthaswamy et al., 2000; Ganesan, 2002a, b, c; Srivastava et al., 2002; ICAR, 2005; Aberkain et al., 2006). However, the feasibility of this technology and its effect on tomato production is not well known in Bangladesh condition. Therefore, the present experiment was conducted to explore the growth, development and yield of tomato crop grown under simple, environmentally friendly and lost cost polyhouse which can be used by the small and marginal farmers of the country.

\section{MATERIALS AND METHODS}

The experiment was conducted at the newly built polyhouse (approximately $15 \times 4.5 \mathrm{~m}$ size) of Crop Botany Field Laboratory, Bangladesh Agricultural University, Mymensingh ( $24^{\circ} 25^{\prime} \mathrm{N}$ latitude and $90^{\circ} 50 " \mathrm{E}$ longitude, $18 \mathrm{masl}$ ) during the period from December 2007 to April 2008. After demarcation of the above measuring rectangular land, the either sides and its central line were marked at equal distance (Approx. $1.5 \mathrm{~m}$ ). A $15 \mathrm{~cm}$ diameter hole to a depth of $50 \mathrm{~cm}$ was augured in all marked points. In the side holes three feet bamboo pegs and in the central holes eight feet bamboo poles were firmly erected by filling the earth around them. Atop of the central poles a bamboo poles was fixed longitudinally across through which bamboo strips were fixed on side pegs in such a way so that it becomes the shape of quonset. The bamboo strips were fixed laterally (length wise) to give more strength to the structure. Ordinary plastic will be tightened around the bamboo strips to reduce the sharp edges which may otherwise damage the polythene sheets. After fabrication of the frame (D-shape) single inflated polyethylene film was spread over the structure from one into the other with extreme care to avoid any puncture or tearing. The polyethylene film should be buried on either side. One gate was installed in the east side of the structure by putting one more poles to regulate the temperature during summer and winter months. To reduce high temperature during summer months, polyethylene film was folded up in the side wall of the house.

The experiment comprised of two factors; (A) two microclimatic treatments viz. polyhouse climate and natural climate (i.e. open field), and (B) two tomato varieties viz. BARI Tomato-3 and Ratan following a Randomized Complete Block Design (RCBD) with four replications. The size of a unit plot was $1 \mathrm{~m} \times 1 \mathrm{~m}$. Two adjacent unit plots and blocks were separated by 0.5 and $0.75 \mathrm{~m}$, respectively. The seedlings of the tomato varieties were collected from the Bangladesh Agricultural Research Institute, Gazipur.

At afternoon, healthy and uniform sized 25 days old seedlings were transplanted on 18 December 2008 in the plots as per experimental design. Rotten cow dung @ $10 \mathrm{t} / \mathrm{ha}$ and other fertilizers (urea, triple super phosphate and muriate of potash @ 550,450 and $250 \mathrm{~kg} / \mathrm{ha}$, respectively) were applied in soil (BARI, 1996). The full dose of cow dung was applied at the time of land preparation. The total amount of triple super phosphate, muriate of potash and half of the amount of uea were mixed to 
the soil one day prior to seedling transplanting. The rest amount of urea was top dressed in two equal installments at 21 and 35 days after transplanting (DAT). Gap filling, weeding, irrigation, pest control and other intercultural practices were performed as and when necessary to optimize the growth and development of the crops.

At daytime, the micrometeorological parameters like photosynthetically active radiation (PAR), air and soil temperatures, and relative humidity $(\mathrm{RH})$ inside the polyhouse and the nearby open field were recorded at hourly interval on January 2, Fabruary 2 and March 3 of 2008. A portable Quantam Sensor (Sky, SKP 2200, UK) was used to record the data on PAR and a portable Psychrometer (Testo 615, Gm 295-14770, Germany) was used to record data on air temperature and $\mathrm{RH}$. These sensors were set at upper leaf level of the plants to avoid the canopy effects. Soil temperature was recorded at $5 \mathrm{~cm}$ depth with soil thermometers covered by metallic case. All the sensors were carefully leveled and calibrated at the beginning of the data collection.

The data on morphological development like plant height, number of branches/plant, leaf area expansion rate and leaf area index (LAI) were collected at 15 days interval starting from 15 DAT (January 2, 2008) to 75 DAT (March 3, 2008). The data on phenological development like days required to first flowering, first fruiting and first fruit maturity, and days to end of fruit harvest were recorded. The number of flower cluster/plant, flower/cluster, flower/plant, fruit cluster/plant and fruit/cluster was counted. The number of fruit/plant was counted and weight of harvested fruit/plant was recorded at weekly interval during fruit development starting from 65 and 93 DAT, respectively. The yield components like number of fruits/plant, fruit length, fruit diameter, weight of individual fruit, weight of fruit/plant, and fruit yield were recorded.

The collected data on different parameters were compiled and analyzed statistically with the computer package MSTAT-C (Russell, 1986). The mean differences were evaluated by Least Significant Difference (LSD) or Duncan's New Multiple Range Test (Gomez and Gomez, 1984).

\section{RESULTS AND DISCUSSION}

\section{Microclimate of the experimental site}

The seasonal trends of daily average value of air and soil temperatures, sunshine hours, relative humidity, and daily total rainfall nearby the Experimental Field Laboratory, Bangladesh Agricultural University, Mymensingh have been presented in the Figure 1.

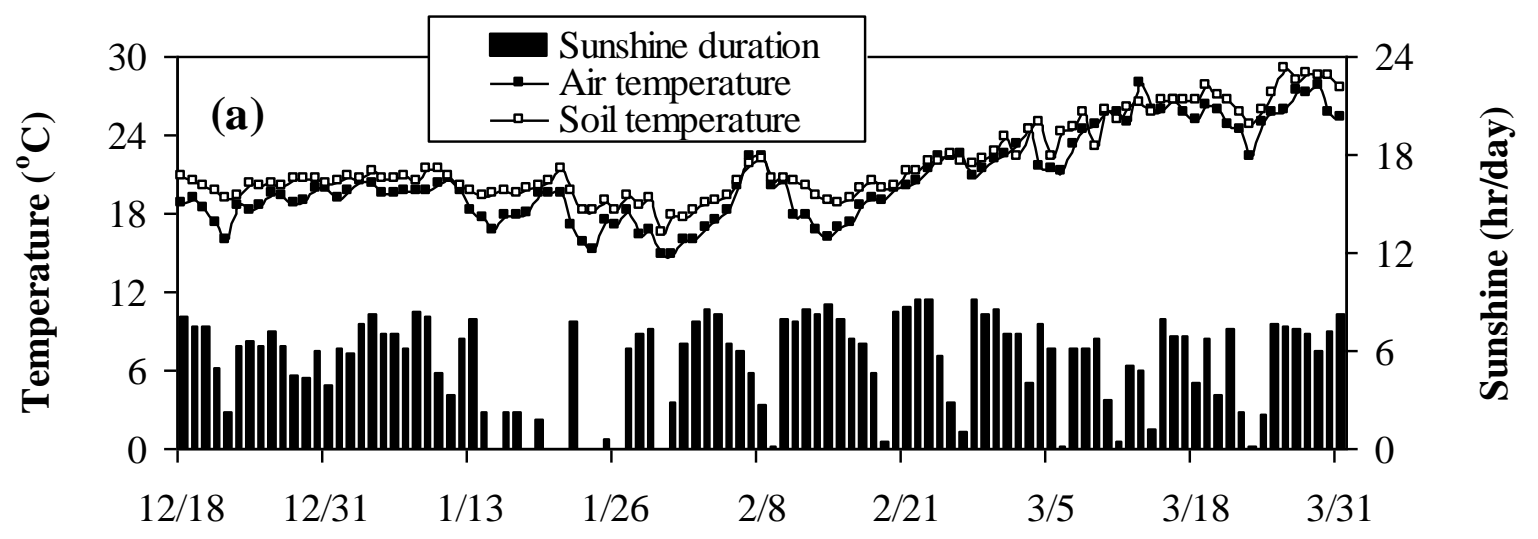




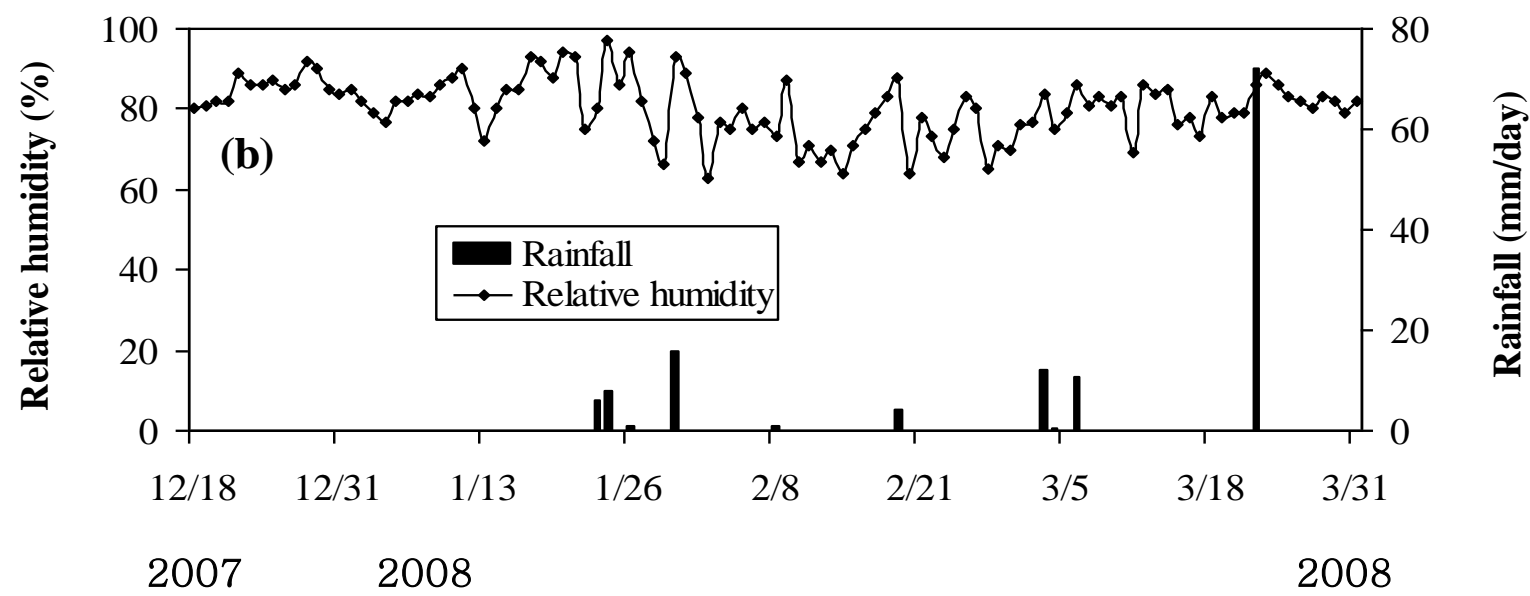

Date (day/month)

Figure 1: Seasonal time-course of (a) air and soil temperatures, and sunshine duration and (b) relative humidity and rainfall in nearby research field at Bangladesh Agricultural University, Mymensingh.

\section{Microclimatic conditions under polyhouse and open field}

The Photosynthetically active radiation (PAR) as measured in three occasions (2 January, 2 February and 3 March, 2008) representing vegetative, reproductive and maturity stages of the tomato plants is presented in Figure 2a-c. The general shapes of the PAR curves at the early vegetative stage (Figure $2 a$ ) and the early reproductive stage (Figure $2 \mathrm{~b}$ ) appeared to be identical where both the days were representative sunny ones and the highest amount of PAR was found at the reproductive stage but the PAR as measured on 3 March 2008 (Figure 2c) had much fluctuation and relatively lower values because of the availability of least amount of sunshine hours (Figure 1). In all fairness at all growth stages and irrespective of the date of measurement, the maximum available PAR inside the polyhouse was about $40 \%$ lower than that of the open field.

The temporal curve of air temperature both within and outside the polyhouse followed a diurnal course i.e. from early lower values gradually increased with the advancement of the day until the peak at around 12:00-13:00 hours, thereafter declined (Figure 2d-f) and these trends were more or less in phase with the solar radiation or PAR (Figure 2a-c). Air temperature inside the polyhouse was distinctly higher than that at the outside. However, the temperature differences between the polyhouse and the open field were small during the early or late hours of the day. With the advancement of the day this difference was amounted to about $8^{\circ} \mathrm{C}$ at around mid days irrespective of the growing stages of the crops. Like air temperature, soil temperature also maintained a distinct diurnal course. Soil under polyhouse always maintained a 2$3^{\circ} \mathrm{C}$ higher temperature as compared to the temperature at the outside soil irrespective of the growing periods of the crop (Figure $2 \mathrm{~g}-\mathrm{i})$.

The diurnal course of relative humidity (RH) always maintained a pattern with more or less opposite to that of the diurnal course of air temperature i.e. lower $\mathrm{RH}$ was found at noon hours, and higher RH was found at morning and evening hours (Figure $2 \mathrm{j}-1$ ). The RH inside the polyhouse was always $5-10 \%$ lower than that of the nearby open field. 



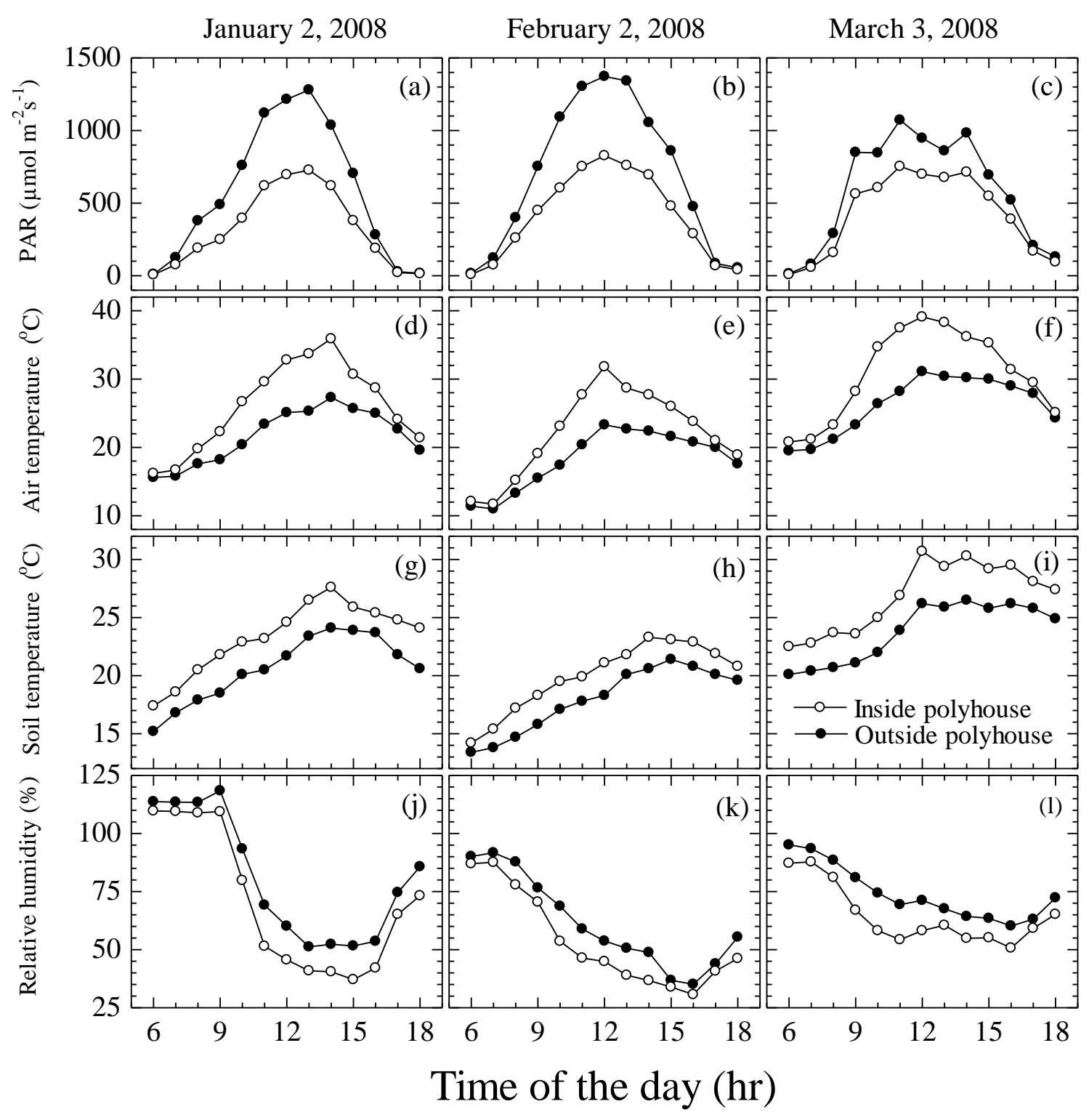

Figure 2: Diurnal time-course of (a-c) photosynthetically active radiation, PAR, (d-f) air temperature, (g-i) soil temperature and $(j-1)$ relative humidity in the polyhouse and nearby outside of the polyhouse at January 2, February 2 and March 3 of 2008.

\section{Morphological development}

Plant height, number of branches per tomato plant, leaf area expansion rate and leaf area index (LAI) steadily increased with season and attained their maxima on 75 DAT (Figure 3a-d). Climatic conditions exerted significant variations on these parameters. The tallest plants, maximum number of branches/plant, higher leaf area expansion rate and LAI were common in the plants grown under polyhouse as compared to natural condition (i.e. open field). Irrespective of the climatic effects two varieties showed significant variation in plant height, number of branches/plant, leaf area expansion rate and LAI especially at the later stages of growth where the variety Ratan exhibited better performances (in most cases) as compared to the BARI Tomato-3 (Table 1a-d). 

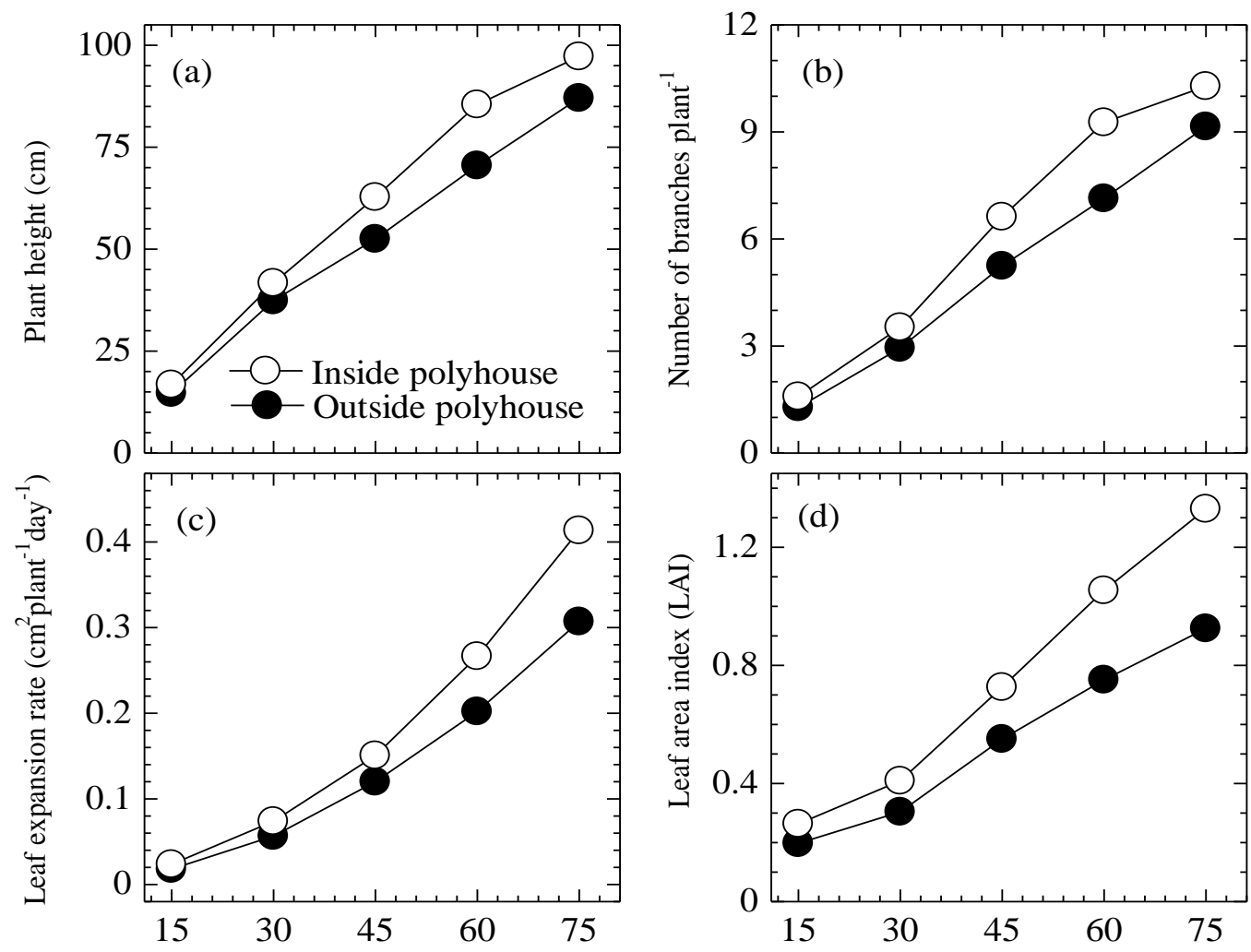

Days after transplanting (DAT)

Figure 3: Seasonal time-course of growth and development of some vegetative events of tomato plants grown under polyhouse and nearby open field: (a) plant height, (b) number of branches per plant, (c) leaf area expansion rate and (d) leaf area index (LAI). Mean difference between the treatments for most of the dates is significant at $5 \%$ level of probability (i.e. $P<0.05$ ).

Table 1: Varietal effect on the plant height, number of branches per plant, rate of leaf area expansion and leaf area index of tomato crop at different growth stages

\begin{tabular}{lcccccccccc}
\hline Variety & \multicolumn{4}{c}{ Days after transplanting (DAT) } & \multicolumn{5}{c}{ Days after transplanting (DAT) } \\
\cline { 2 - 11 } & 15 & 30 & 45 & 60 & 75 & 15 & 30 & 45 & 60 & 75 \\
\hline (a) Plant height $(\mathrm{cm})$ & & & & & \multicolumn{5}{c}{ (b) Number of branches/plant } \\
BARI Tomato-3 & $15.5 \mathrm{~b}$ & $38.6 \mathrm{~b}$ & $56.9 \mathrm{~b}$ & $76.8 \mathrm{~b}$ & $91.0 \mathrm{~b}$ & 1.4 & $3.1 \mathrm{~b}$ & $5.7 \mathrm{a}$ & $8.0 \mathrm{~b}$ & 9.8 \\
Ratan & $16.0 \mathrm{a}$ & $40.5 \mathrm{a}$ & $58.4 \mathrm{a}$ & $79.2 \mathrm{a}$ & $93.3 \mathrm{a}$ & 1.5 & $3.3 \mathrm{a}$ & $6.1 \mathrm{~b}$ & $8.4 \mathrm{a}$ & 9.7 \\
$\quad$ LSD $_{0.05}$ & 0.33 & 0.81 & 0.50 & 0.55 & 0.68 & NS & 0.16 & 0.09 & 0.09 & NS
\end{tabular}

(c) Rate of leaf area expansion $\left(\mathrm{cm}^{2} /\right.$ plant/day)

(d) Leaf area index (LAI)

\begin{tabular}{lcccccccccc} 
BARI Tomato-3 & 8.1 & 21.3 & $45.0 \mathrm{~b}$ & 41.9 & $41.9 \mathrm{a}$ & 0.23 & 0.36 & $0.63 \mathrm{~b}$ & $0.88 \mathrm{~b}$ & 1.13 \\
Ratan & 8.7 & 20.9 & $49.0 \mathrm{a}$ & 46.2 & $32.0 \mathrm{~b}$ & 0.23 & 0.36 & $0.65 \mathrm{a}$ & $0.93 \mathrm{a}$ & 1.13 \\
\multicolumn{1}{c}{ LSD $_{0.05}$} & NS & NS & 3.40 & NS & 7.82 & NS & NS & 0.01 & 0.04 & NS \\
\hline
\end{tabular}

Similar letter within a column do not differ significantly at $5 \%$ level of probability.

LSD = Least Significant Difference, NS = Non Significant. 


\section{Phenological development}

Tomato plants grown inside the polyhouse hastened first flowering, first fruiting and first maturity by about 3, 4 and 5 days, respectively as compared to the plants grown in the outside natural condition (Figure 4). Polyhoused plants prolonged the duration of fruit harvest by about 9 days. The varietals effect was found to be significant for days required to first maturity and end of fruit harvest but insignificant for days required to first flowering and first fruiting (Table 2).

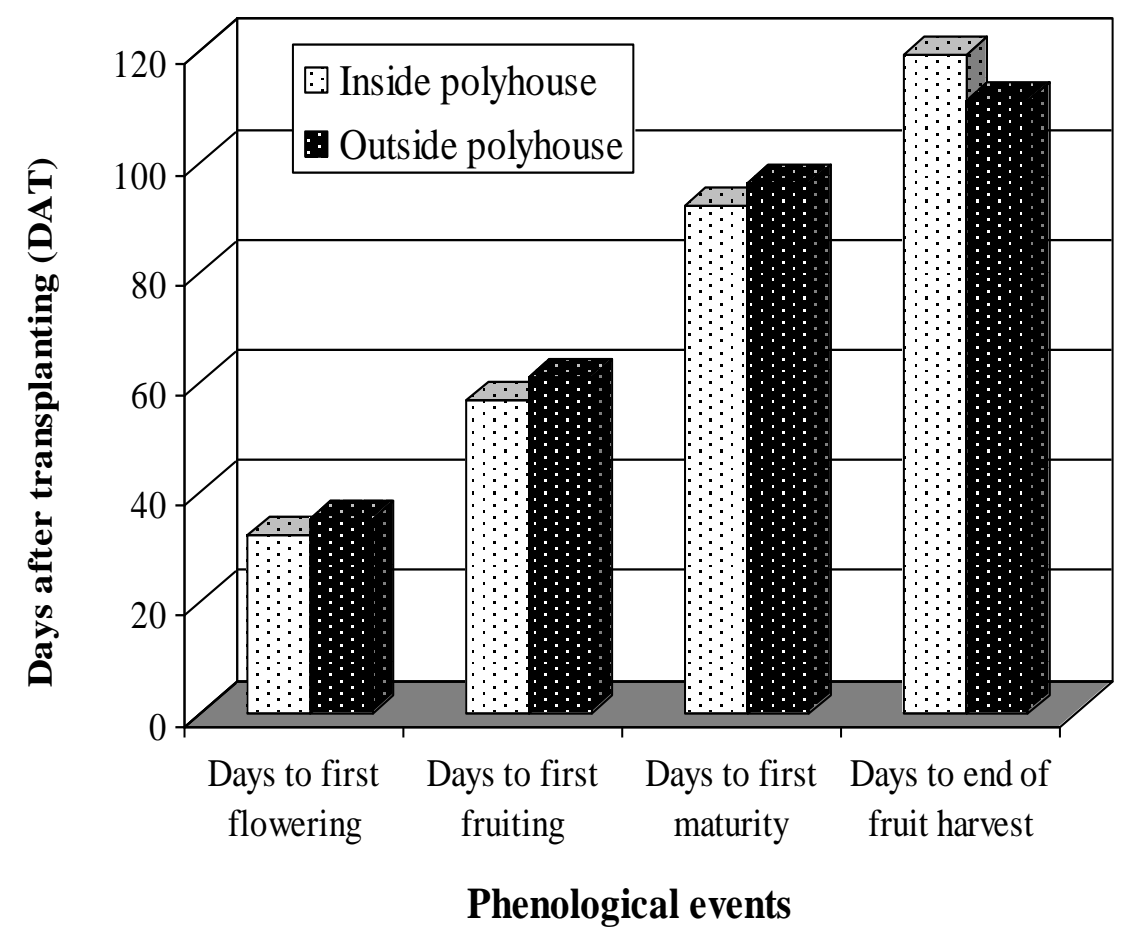

Figure 4: Days to first flowering, first fruiting, first maturity and end of fruit harvest of tomato plants grown inside the polyhouse and nearby open field. Mean difference between the treatments for all the phonological events is significant at $5 \%$ level of probability (i.e. $P<0.05$ ).

Table 2: Varietal effect on phenological development of tomato plants grown under polyhouse climate and open field

\begin{tabular}{|c|c|c|c|c|}
\hline Treatments & $\begin{array}{c}\text { Days to } \\
\text { first flowering }\end{array}$ & $\begin{array}{l}\text { Days to first } \\
\text { fruiting }\end{array}$ & $\begin{array}{l}\text { Days to first } \\
\text { maturity }\end{array}$ & $\begin{array}{l}\text { Days to end of } \\
\text { fruit harvest }\end{array}$ \\
\hline BARI Tomato-3 & 33.7 & 59.2 & $95.8 \mathrm{a}$ & $114.4 \mathrm{~b}$ \\
\hline Ratan & 33.3 & 58.6 & $93.3 \mathrm{~b}$ & $116.0 \mathrm{a}$ \\
\hline $\mathrm{LSD}_{0.05}$ & NS & NS & 1.10 & 0.61 \\
\hline
\end{tabular}

Similar letter within a column do not differ significantly at $5 \%$ level of probability.

LSD $=$ Least Significant Difference, NS = Non Significant. 


\section{Reproductive development}

Polyhoused plants had significantly higher number of flower clusters/plant, flowers/cluster, flowers/plant, number of fruit clusters/plant and fruits/cluster than the plants grown in open field (Table 3a).
The tomato variety BARI Tomato-3 showed significantly higher number of flower clusters/plant, flowers/cluster and flowers/plant as compared to Ratan (Table $3 b)$.

Table 3: Salient features of reproductive development of tomato plants grown under polyhouse climate and open field

\begin{tabular}{lccccc}
\hline Treatments & $\begin{array}{c}\text { Number of } \\
\text { flower clusters } \\
\text { plant }^{-1}\end{array}$ & $\begin{array}{c}\text { Number of } \\
\text { flowers } \\
\text { cluster }^{-1}\end{array}$ & $\begin{array}{c}\text { Number of } \\
\text { flowers } \\
\text { plant }^{-1}\end{array}$ & $\begin{array}{c}\text { Number of } \\
\text { fruit clusters } \\
\text { plant }^{-1}\end{array}$ & $\begin{array}{c}\text { Number } \\
\text { of fruits }^{\text {cluster }}\end{array}$ \\
\hline (a) Climatic effect & $10.8 \mathrm{~b}$ & $3.7 \mathrm{~b}$ & $39.5 \mathrm{~b}$ & $4.5 \mathrm{~b}$ & $4.2 \mathrm{~b}$ \\
Natural climate & $13.6 \mathrm{a}$ & $4.5 \mathrm{a}$ & $60.8 \mathrm{a}$ & $5.3 \mathrm{a}$ & $5.1 \mathrm{a}$ \\
Polyhouse climate & 0.39 & 0.27 & 0.82 & 0.24 & 0.29 \\
$\quad$ LSD 0.05 & $12.57 \mathrm{a}$ & $4.21 \mathrm{a}$ & $53.72 \mathrm{a}$ & 5.02 & 4.71 \\
(b) Varietal effect & $11.80 \mathrm{~b}$ & $3.90 \mathrm{~b}$ & $46.54 \mathrm{~b}$ & 4.80 & 4.52 \\
BARI Tomato-3 & 0.39 & 0.27 & 0.82 & $\mathrm{NS}$ & $\mathrm{NS}$ \\
Ratan & & & & \\
\multicolumn{1}{c}{ LSD $_{0.05}$} & & & & & \\
\hline
\end{tabular}

Similar letter within a column do not differ significantly at 5\% level of probability.

LSD $=$ Least Significant Difference, NS = Non Significant.
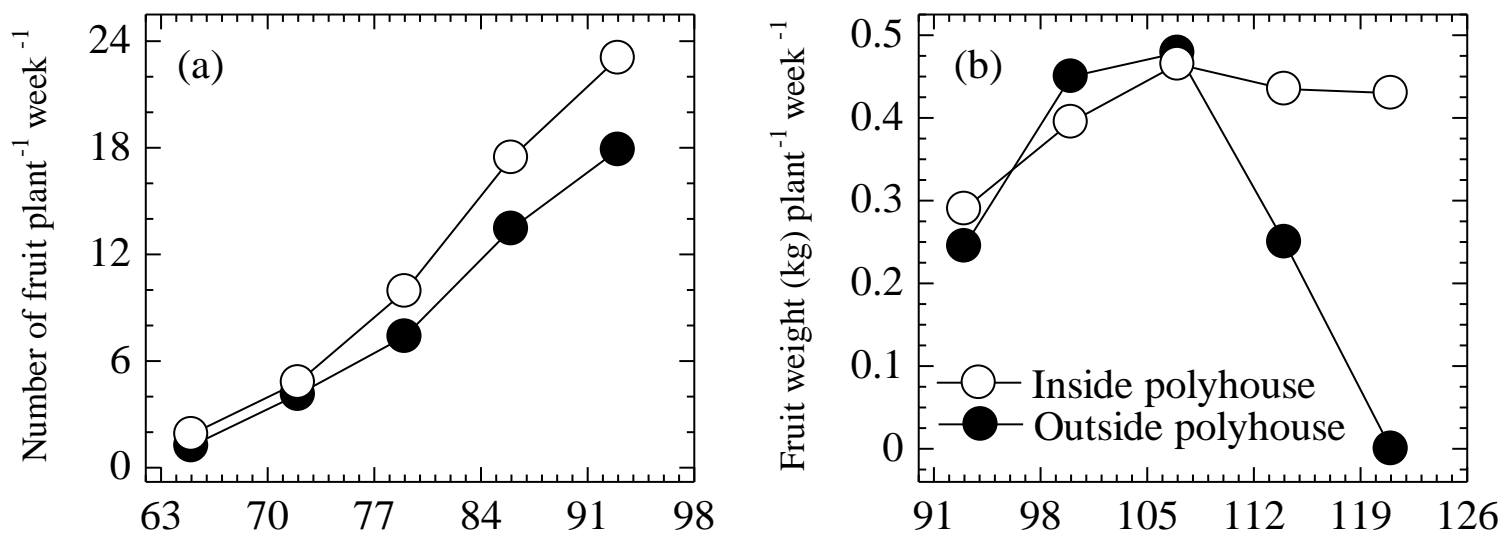

Days after transplanting (DAT)

Figure 5: (a) Number of fruit/plant and (b) fruit weight/plant harvested weekly from the tomato plants grown inside the polyhouse and nearby open field. Mean difference between the treatments for most of the dates is significant at $5 \%$ level of probability (i.e. $P<0.05$ ). 
The number of fruits/plant/week gradually increased from 65 DAT to maturity with higher values in the plants grown under polyhouse (Figure 5a). On the other hand the plants grown under polyhouse showed regular pattern in weight for harvested fruit weight/plant/week (Figure 5b), however the plants grown at open field exhibited irregular pattern with drastic reduction of fruit weight from 107 DAT towards maturity.

The influence of different varieties on the number of fruits/plant/week was found significant throughout the fruit growing season where BARI Tomato-3 produced the higher number of fruit as compared to Ratan (Table 4). But the varietals effect throughout the season was found to be insignificant for fruit weight/plant/week except at 121 DAT.

\section{Yield contributing characters and yield}

The number of fruits/plant, fruit length and diameter, individual fruit weight, fruit weight/plant and fruit yield of tomato crop grown under polyhouse were significantly higher than the crop grown in the open field (Table 5a). Individual tomato fruits obtained from polyhouse were about $10 \%$ bigger than the fruits obtained from the plants grown in open field. The tomato plants grown with polyhouse climate produced $29 \%$ higher fruit yield than the tomato plants grown at the outside of polyhouse. The two varieties showed significant variation for the number fruit/plant, individual fruit weight and fruit weight/plant but insignificant variation was found for fruit length, fruit diameter and yield (Table 5b).

Table 4: Varietal effect on the number and weight of weekly harvested fruit per plant at different DAT of tomato plants

\begin{tabular}{lcccccccccc}
\hline \multirow{2}{*}{ Variety } & \multicolumn{3}{c}{ Number of fruits/plant/week at different DAT } & \multicolumn{5}{c}{ Fruit weight (kg/plant/week) at different DAT } \\
\cline { 2 - 11 } & 65 & 72 & 79 & 86 & 93 & 93 & 100 & 107 & 114 & 121 \\
\hline BARI Tomato-3 & $1.77 \mathrm{a}$ & $4.87 \mathrm{a}$ & $9.63 \mathrm{a}$ & $16.7 \mathrm{a}$ & $21.6 \mathrm{a}$ & 0.260 & 0.415 & 0.470 & 0.345 & $0.20 \mathrm{~b}$ \\
Ratan & $1.35 \mathrm{~b}$ & $4.06 \mathrm{~b}$ & $7.68 \mathrm{~b}$ & $14.2 \mathrm{~b}$ & $19.4 \mathrm{~b}$ & 0.275 & 0.430 & 0.473 & 0.340 & $0.23 \mathrm{a}$ \\
$\quad$ LSD $_{0.05}$ & 0.06 & 0.04 & 0.07 & 0.10 & 0.06 & $\mathrm{NS}$ & $\mathrm{NS}$ & $\mathrm{NS}$ & $\mathrm{NS}$ & 0.01 \\
\hline
\end{tabular}

Similar letter within a column do not differ significantly at 5\% level of probability.

LSD $=$ Least Significant Difference, NS = Non Significant.

Table 5: Yield components and yield of tomato plants grown under polyhouse climate and open field

\begin{tabular}{|c|c|c|c|c|c|c|}
\hline Treatments & $\begin{array}{l}\text { Number } \\
\text { of fruits } \\
\text { plant }^{-1}\end{array}$ & $\begin{array}{l}\text { Fruit } \\
\text { length } \\
(\mathrm{cm})\end{array}$ & $\begin{array}{c}\text { Fruit } \\
\text { diameter } \\
(\mathrm{cm})\end{array}$ & $\begin{array}{l}\text { Individual } \\
\text { fruit weight } \\
\quad(\mathrm{g})\end{array}$ & $\begin{array}{c}\text { Fruit weight } \\
\text { plant }^{-1} \\
(\mathrm{~kg})\end{array}$ & $\begin{array}{l}\text { Fruit } \\
\text { yield } \\
\left(\mathrm{t} \mathrm{ha}^{-1}\right)\end{array}$ \\
\hline \multicolumn{7}{|l|}{ (a) Climatic effect } \\
\hline Natural climate & $19.2 \mathrm{~b}$ & $3.8 \mathrm{~b}$ & $4.9 \mathrm{~b}$ & $74.1 \mathrm{~b}$ & $1.4 \mathrm{~b}$ & $57.2 \mathrm{~b}$ \\
\hline Polyhouse climate & $24.5 \mathrm{a}$ & $4.4 \mathrm{a}$ & $5.4 \mathrm{a}$ & $82.7 \mathrm{a}$ & $2.0 \mathrm{a}$ & $80.6 \mathrm{a}$ \\
\hline $\mathrm{LSD}_{0.05}$ & 0.87 & 0.57 & 0.49 & 0.94 & 0.05 & 3.91 \\
\hline \multicolumn{7}{|l|}{ (b) Varietal effect } \\
\hline BARI Tomato-3 & $22.98 \mathrm{a}$ & 3.88 & 4.985 & $73.05 \mathrm{~b}$ & $1.69 \mathrm{~b}$ & 67.60 \\
\hline Ratan & $20.71 \mathrm{~b}$ & 4.26 & 5.275 & $84.00 \mathrm{a}$ & $1.76 \mathrm{a}$ & 70.20 \\
\hline $\mathrm{LSD}_{0.05}$ & 0.87 & $\mathrm{NS}$ & NS & 0.94 & 0.05 & NS \\
\hline
\end{tabular}

Similar letter within a column do not differ significantly at $5 \%$ level of probability.

LSD = Least Significant Difference, NS = Non Significant. 

The lower amount of incident PAR under polyhouse as compared to the open field was due to the greater inference of the roof of polyhouse against the incoming solar beam. Although polyhouse permits easy entrance of short-wave radiation but traps the outgoing long-wave radiation. As a result the air temperature inside the polyhouse gradually increased due to the greenhouse effect. Thus, the inner of the polyhouse becomes warm to warmer and temperature remained at optimum level (about $28^{\circ} \mathrm{C}$ ) for the growth and development of tomato plants during the cooler months (December to February). Such warmer air inside the polyhouse induced the soil warming. Therefore, soil temperature was also higher under polyhouse than open field (Montero and Anton, 2003). The minimum value of relative humidity in the polyhouse was common because of its inverse function with higher air temperature. Morphological development like plant height, number of branches per tomato plant, leaf area expansion rate and leaf area index were positively favoured due to the warmer environment inside the polyhouse (Duhr and Dubas, 1990; Miah (2001; Pandey et al., 2004) in spite of lower amount of PAR .

Polyhouse climate influenced the crops to open flower and mature of fruits earlier than open field (Nagalakshmi et al., 2001; Cheema et al., 2004; Kang and Sidhu, 2005) due to the advancement of required heat unit or thermal time of the crops (Awal and Ikeda, 2003a) grown inside the polyhouse. It is reported that the rate of development in peanut toward emergence, flowering and podding was positively associated with soil temperature (Awal and Ikeda, 2002). Early maturity is one of the important aspects for harvesting of fruit earlier. Total fruit bearing period was also prolonged under polyhouse. For that reason total number of fruit harvests was more in polyhouse than open field (Pandey et al., 2004).
Significantly higher fruit yield in the plants grown under polyhouse condition over the plants grown in open space was associated with the production of higher number of fruits with greater length and diameter than those in the open field. Higher values of all the yield components and yield of tomato crop grown under polyhouse than open field was due to the taller plants and much number of branches with greater LAI attributed by warmer temperature and the results are in agreement with Kanthaswamy et al. (2000), Gaikwad and Dumbre (2001), Nagalakshmi et al. (2001), Saikia et al. (2001), Gaikwad et al., (2002), Srivastava et al. (2002), Ganesan, (2002a, b, c), Mishra et al. (2003) and Kang and Sidhu (2005) although lower amount of available PAR under polyhouse could not affect the growth and yield of tomato (Aberkain et al., 2006; Marcelis et al., 2006).

An optimum day temperature of $28^{\circ} \mathrm{C}$ is required for better production of tomato (Sato et al., 2006 and Adil et al., 2004) which remained in the polyhouse during December to February whereas the ambient temperature was far below than the optimum which affected the growth, development and ultimately yield of tomato. Rate of leaf initiation and expansion of its area, and net photosynthesis rate decreased with decreasing temperature (Huang et al., 2002; Van der Ploeg and Heuvelink, 2005). Baytorum et al., (1999) mentioned that tomato yield was higher in heated greenhouse than in unheated greenhouse up to the end of March. The lower minimum temperature levels reduced or delayed the fruiting process of tomato (Romano and Leonard, 1994) and it might create problems for the vegetative and generative growth (Abak and Guler, 1994). The leaf temperature of $13^{\circ} \mathrm{C}$ may cause the reduction in physiological activity of cucumber plants due to low temperature stress (Roh et al., 2007) and it prevent fertilization in tomato by reducing pollen 
count and viability (Ercan and Vural, 1994) and therefore, decreases fruit set and the yield (Rylski et al., 1994).

Since hi-tech glasshouse technology requires huge initial investments where production cost is to be very high. The small and marginal farmers cannot afford that technology due to high capital investment. Hence, low cost with locally available materials like bamboo and transparent polyethylene have been found quite effective for nursery raising and offseason production of tomato which fetched premium prices in the market.

\section{CONCLUSIONS}

It is concluded that the better growth, development and yield of tomato were achieved under polyhouse due to the higher (optimum) temperature and lower relative humidity during the winter months (December to February) which positively influenced the morpho-phenological and physiological events of tomato plants. This simple and low cost polyhouse may be suitable for subtropical regions like Bangladesh where the temperature falls during winter. The growth and development of tomato plant becomes restricted during the cold winter months of December to February because of its season bound nature. Therefore, if tomato is planted under polyhouse, it will establish good stands that mature earlier. The optimum temperature accompanied by low relative humidity inside polyhouse hasten crop development and early maturity, so growers are benefited by being able to produce higher and offseason tomato which fetched premium prices in the market.

\section{REFERENCES}

Abak, K. and H.Y. Guler (1994). Pollen fertility and the vegetative growth of various eggplant genotypes under low temperature greenhouse conditions. Acta Horticulturae (ISHS), 366, pp: 85-92.

Aberkain, K., A. Gosselin, S. Vineberg, and M. Dorais (2006). Effects of insulating foams between double polyethylene films on light transmission, growth and productivity of greenhouse tomato plants grown under supplemental lighting. Acta Horticulturae (ISHS), 711, pp: 449-454.

Adil, H., A. Abdelmageed, N. Gruda, and B. Geyer (2004). Effects of temperature and grafting on the growth and development of tomato plants under controlled conditions. Rural Poverty Reduction through Research for Development and Transformation. Deutscher Tropentag, Berlin.

Awal, M.A. and T. Ikeda (2002). Effects of changes in soil temperature on seedling emergence and phenological development in field-grown stands of peanut (Arachis hypogaea L.). Environmental and Experimental Botany, 47 (2), pp: 101-113.

Awal, M.A. and T. Ikeda (2003a). Effect of elevated soil temperature on radiation-use efficiency in peanut stands. Agricultural and Forest Meteorology, 118 (1-2), pp: 6374.

Awal, M.A. and T. Ikeda (2003b). Controlling canopy formation, flowering, and yield in field-grown stands of peanut (Arachis hypogaea L.) with ambient and regulated soil temperature. Field Crops Research, 81 (2-3), pp: 121-132.

Awal, M.A., T. Ikeda and R. Itoh (2003). The effect of soil temperature on source-sink economy in peanut (Arachis hypogaea). Environmental and Experimental Botany, 50 (1), pp: 41-50.

BARI. (1996). Summer Tomato (Booklet in Bengali). Horticulture Research Centre, 
Bangladesh Agricultural Research Institute, Joydebpur, Gazipur, pp: 12.

Baytorum, A.X., S. Topcu, K. Abak, and Y. Dasgan (1999). Growth and production of tomatoes in greenhouses at different temperature levels. Gartenbauwissenschaft, 64 (1), pp; 33-39.

BBS. (2008). Statistical Year Book. Agricultural Statistics of Bangladesh. Bangladesh Bureau of Statistics, Statistics Division, Ministry of Planning. Govt. People's Repub. Bangladesh, Dhaka, pp: 137.

Cheema, D.S., P. Kaur, and S. Kaur (2004). Off-season cultivation of tomato under net house conditions. Acta Horticulturae (ISHS), 659, pp: 177-181.

Duhr, E. and A. Dubas (1990). Effect shading the soil with plastic film on the dynamics of plant development and yield of maize sown on different dates. Prce Kumisji Nouk Rolnicsy Ch-1-Kamiji-lesnych, 69, pp: 9-18.

Ercan, N. and H. Vural (1994). The effects of low temperatures on fruit set of tomatoes. Acta Horticulturae (ISHS), 366, pp: 65-72.

Gaikwad, A.M. and P.S.S. Dumbre (2001). Evaluation of chrysanthemum varieties under open and polyhouse conditions. Journal of Ornamental Horticulture, New Series, 4 (2), pp: 95-97.

Gaikwad, A.M., S.M. Katwate, and C.A. Nimbalkar (2002). Evaluation of chrysanthemum varieties under polyhouse conditions. South Indian Horticulture, 50 (4/6), pp: 624628.

Ganesan, M. (2002a). Comparative evaluation of low cost poly-greenhouse and its effect on the yield and quality of two varieties of tomato (Lycopersicon esculentum Mill). Indian Agriculturist, 46 (3/4), pp. 161-168.

Ganesan, M. (2002b). Effect of poly-greenhouse models on plant growth and yield of tomato (Lycopersicon esculentum). Indian Journal of Agricultural Sciences, 72 (10), pp: 586588.

Ganesan, M. (2002c). Effect of poly-greenhouse on plant micro climate and fruit yield of tomato. Karnataka Journal of Agricultural Sciences, 15 (4), pp: 750-752.

Gomez, K.A. and A.A. Gomez (1984). Statistical Procedures for Agricultural Research. International Rice Research Institute, John Wiley \& Sons, New York. pp: 139-240.

Huang, W., Z. Ren-Hua, and M. Zhang-Fu (2002). Effects of low temperature and weak light on growth and photosynthesis of tomato. China-Vegetables, 4, pp:15-17.

ICAR (Indian Council of Agricultural Research, Krishi Bhavan). (2005). Low cost polythene technology for off-season vegetable production. Dr Mangala Rai, Secretary (DARE) and Director-General, ICAR, New Delhi 110 001, India, Vol. 11 No. 2 April-June 2005.

Kang, B.S. and B.S. Sidhu (2005). Studies on growing off-season tomato nursery under polyhouse. Annals of Agri Bio Research, 10 (1), pp: 53-56.

Kanthaswamy, V., S. Narendra, D. Veeraragavathatham, K. Srinivasan, and S. Thiruvudainambi (2000). Studies on growth and yield of cucumber and sprouting broccoli under polyhouse condition. South Indian Horticulture, 48 (1/6), pp: 47-52.

Marcelis, L. F.M., A. G. M. Broekhuij-sen, F. Meinen, F. M. F. M. Nijs, and M. G. M. Raaphorst (2006). Quantification of the growth response to light quantity of greenhouse-grown crops. Acta Horticulturae (ISHS), 711, pp: 97-103.

Miah, M. M. (2001). Performance of five winter vegetables under different light conditions for Agroforesty systems. M. S. Thesis, BSMRAU, Gazipur, Bangladesh.

Mishra, J.N., B.K. Molianty, P.C. Pradhan, and P. Naik (2003). Study on biometric characteristics of okra in greenhouse. Orissa Journal of Horticulture, 31 (1), pp: 112113.

Montero, J.J., and A. Anton (2003). Greenhouse characteristics and microclimatic conditions. 
Acta Horticulturae (ISHS), 614, pp: 323-333.

Nagalakshmi, S., N. Nandakumar, D. Palanisamy, and V.V. Sreenarayanan (2001). Naturally ventilated polyhouse for vegetable cultivation. South Indian Horticulture, 49 (Special), pp: 345-346.

Pandey, V.K., S.K. Dwivedi, A. Pandey, and H.G. Sharma (2004). Low cost polyhouse technology for vegetable cultivation in Chhattisgarh Region. Plant Archives, 4 (2), pp: 295-301.

Roh, M.Y., Y.I. Nam, M.W. Cho, I.H. Yu, G.L. Choi, and T.Y. Kim (2007). Environmental control in greenhouse based on phytomonitoring of leaf temperature as a factor controlling greenhouse environments. Acta Horticulturae (ISHS), 761, pp: 71-76.

Romano, D. and C. Leonardi (1994). The responses of tomato and eggplant to different minimum air temperatures. Acta Horticulturae (ISHS), 366, pp: 57-64.

Russell, D. F. (1986). MSTAT-C. MSTAT Director, Crop and Soil Science Department, Michigan State University, USA.

Rylski, I., B. Aloni, L. Karni, and Z. Zaidman (1994). Flowering, fruit set, fruit development and fruit quality under different environmental conditions in tomato and pepper crops. Acta Horticulturae (ISHS), 366, pp: 45-56.

Saikia, J., H.K. Baruah, and D.B. Phookan (2001). Off season production of cucumber inside lowcost polyhouse. Annals of Biology, 17 (1), pp: 61-64.

Sato, S., M. Kamiyama, T. Iwata, N. Makita, H. Furukawa, and H. Ikeda (2006). Moderate increase of mean daily temperature adversely affects fruit set of Lycopersicon esculentum by disrupting specific Physiological Processes in Male Reproductive Development. Annals of Botany, 97(5), pp: 731-738.

Srivastava, P., B.K. Srivastava, and M.P. Singh (2002). Effect of date of planting and growing environment on the plant survival, growth and yield of early cauliflower in rainy season. Vegetable Science, 29 (2), pp: 157-160.

Van der Ploeg, A. and E. Heuvelink (2005). Influence of sub-optimal temperature on tomato growth and yield: a review. Journal of Horticultural Science \& Biotechnology, 80 (6), pp: 652-659. 